\title{
Principles for legal regulation of relations of aquaculture (fish farming)
}

\author{
Anna Kudaeva $^{1 *}$ and Svetlana Zyablitseva ${ }^{2}$ \\ ${ }^{1}$ Institute of Service and Entrepreneurship (branch) of DSTU in Shakhty, str., 147, Shevchenko, \\ 346500, Russia \\ ${ }^{2}$ Institute of Service and Entrepreneurship (branch) of DSTU in Shakhty, str., 147, Shevchenko, \\ 346500, Russia
}

\begin{abstract}
The article is devoted to the topic «Principles for legal regulation of relations in the field of aquaculture (fish farming). The normative-legal basis of legal regulation of relations in the field of aquaculture (fish farming) is investigated. The management and support of legal regulation of relations in the field of aquaculture (fish farming) is relevant since 1970 in the production of aquaculture products is observed only growth, indicating the importance of the agricultural sector within countries and on a global scale. Currently, aquaculture is considered not only as an activity that meets the needs of food producers, but also as a means of economic growth and achieving a variety of social and environmental goals. Awareness of the need for accelerated development of aquaculture leads to the adoption of appropriate laws and strategies to regulate its activities. This branch of agricultural production developed gradually by experience, taking into account traditions, mistakes made and through joint activities. Aquaculture has grown and integrated into the natural, social, economic and cultural environment. The sector is growing at an unprecedented rate and currently supplies more than half of the world's fish for human consumption.
\end{abstract}

\section{Introduction}

Fishing has always been considered one of the branches of agriculture. However, fish production has not always successfully met the needs of the population for fish products. International organizations are monitoring the rapid growth of the world's population, which requires additional sources of food. At the same time, the problem of global poverty has not yet been solved. According to world sources, the number of people who are malnourished or malnourished is increasing due to lack of income or low income levels.

\footnotetext{
* Corresponding author: aveaduk@rambler.ru
} 
Global warming has also contributed to a decline in marine and oceanic fisheries, especially in Africa. Since 1970, the fishing Powers have noted a decrease in the volume of oceanic fishing. At the same time, according to economic forecasts, fish production in freshwater reservoirs would never make up for the level of catch of aquatic bio-resources that was previously extracted. These and other circumstances formed the basis for the revival and development of such an area of fish farming as aquaculture.

Aquaculture or fish farming is the artificial breeding, maintenance, cultivation and sale of aquaculture objects such as various types of fish, crustaceans, shellfish, algae. Fish farming is carried out mainly in conditions created by man, with rare exceptions in the natural environment, but under human control. The purpose of aquaculture is to replenish water bodies with grown aquatic organisms for further production of aquaculture products and the provision of recreational services.

In recent decades, it has become clear that the role of fisheries and aquaculture in providing food, nutrition and employment is increasing. With proper fisheries management, the world's stocks of aquatic bio-resources are constantly above the target level or are being restored. However, the success achieved by a number of countries and regions in the field of aquaculture is not sufficient to prevent the global trend towards the destruction of water resources. In those States where fishing is not regulated or carried out inefficiently, the state of fish stocks is gradually decreasing. In this regard, there is a need for international dissemination of the most successful aquaculture projects, close cooperation of states, in order to provide assistance in those areas where the fishing of water resources is low. It is necessary to create new mechanisms that promote more rational exploitation of fish resources and ecosystems, without which it is impossible to ensure the sustainability of global fisheries.

In addition, it becomes clear that the competent implementation of aquaculture has the least impact on the natural environment. Fish products are not only the healthiest food for humans, but their production is much more environmentally friendly, relative to other types of economic activity.

The Food and Agriculture Organization of the United Nations (FAO) which conducts annual monitoring of the world fish economy, claims that the development of industrial fisheries will continue in the future. Since 1970, there has been only an increase in the production of aquaculture products, which indicates the importance of this branch of agriculture both within countries and on a global scale. Aquaculture in the world continues to expand, becoming more diverse, intensive and technologically advanced. In terms of growth, it still occupies a dominant position among the livestock sectors. The potential of aquaculture will be realized in the future and will help to solve large-scale environmental problems. However, industrial fish farming needs to build on technological advances in feed production, selective breeding, biosafety and disease control, use innovative digital solutions and new approaches to entrepreneurship in the field of investment and trade.

Currently, aquaculture is considered not only as an activity that meets the needs of food producers, but also as a means of economic growth and achieving a variety of social and environmental goals [1]. Awareness of the need to accelerate the development of aquaculture leads to the adoption of appropriate laws and policies governing its activities.

States with developed aquaculture take measures to promote this field of activity. Many countries recognize aquaculture as a priority area of economic development, developing appropriate strategies for the effective implementation of fish farming. At the level of local farms, the state adheres to the» start-up " policy, finances the development and research of aquaculture enterprises, provides economic entities with planting material, provides consulting services, and provides preferential loans [2]. State support for the field of aquaculture is accompanied by control over the use of medicinal products, growth 
promoters and safe feed production. Special attention is paid to the processing and packaging of aquaculture products to prevent diseases and ensure the safety of consumers.

Taking into account the positive forecasts of the world's communities, aquaculture will continue to be a priority in national, regional and global food security and nutrition strategies. Aquaculture will help to restore the ecological balance between consumption and production, as well as eliminate hunger and malnutrition.

Russia is not the last place in the world of aquaculture. The development and growth of commercial aquaculture began in the $80 \mathrm{~s}$, due to the introduction of new technologies, the improvement of the principles and systems of farming, and the gradual transition to a market economy model. Statistics show an increase in the production of commercial fish by $10-15 \%$. This is one of the best indicators in the world of aquaculture.

After lengthy public discussions, Federal Law No. 148-FZ «On Aquaculture (Fish Farming) and on Amendments to Certain Legislative Acts of the Russian Federation» (hereinafter referred to as the Law on Aquaculture) was adopted on July 02, 2013[3]. The adoption of the law provided the beginning of the creation of a much-needed comprehensive legislative framework regulating legal relations in the field of aquaculture (fish farming).

\section{Methods and subject of the study}

The methodological basis is a systematic approach, which focuses the research on the study of the fundamental principles of legal regulation of relations in the field of aquaculture (fish farming), laid down by the domestic legislator as the basis of the Law on Aquaculture.

Based on this goal, it is necessary to solve the following tasks: first, to determine an exhaustive list of principles of legal regulation of aquaculture (fish farming); second, whether or not there is a need to supplement the Law on Aquaculture with new principles of legal regulation of this area of fish farming.

It should be noted that there are no separate comprehensive scientific works on topical issues of aquaculture in international law, domestic and foreign literature, which is explained by the practical orientation of the industry, as well as its insufficient age maturity.

Theoretical developments of a general nature deserve attention: the monograph of A. N. Vylegzhanin «Marine natural resources», the joint monograph of A. N. Vylegzhanin and V. $\mathrm{K}$. Zilanov «International legal bases of marine living resources management (theory and documents)», the monograph of K. A. Bekyashev and V. D. Sapronov «World fisheries: issues of international cooperation», the book of A. A. Krayniy and K. A. Bekyashev «International problems of combating IUU fishing: policy and law».

After the adoption of the Law on Aquaculture, an article-by-article scientific and practical commentary to the Federal Law «On Aquaculture (Fish Farming) and on Amendments to Certain Legislative Acts of the Russian Federation» was published under the general editorship of A.V. Gabov. The team of commentators uses relevant international treaties, legislative acts of foreign states, judicial acts, other acts and even technical documentation used in the field of aquaculture, provides examples from the experience of fish farming with elements of describing biotechnological processes.

The problems of aquaculture at the present stage are partially addressed in the monograph of L. I. Broslavsky " Technical regulation and standardization of product quality and environmental safety. Laws and realities of Russia, the United States and the European Union».

From foreign sources in the field under consideration, it is worth noting the collective monograph edited by O. S. Stoke, Professor of Law at the University of Oslo (Norway), «Management of fisheries on the high seas. Interaction of universal and regional regimes», 
published in 2001. In the monograph of the Professor of Law of the University. James Cook (Australia) S. Kaye «International Fisheries Management», published in 2001, focuses on precautionary and ecosystem approaches in fisheries management, as well as a number of regional issues.

For an integrated analysis of modern theoretical and legislative disclosure of aquaculture, it is advisable to use international instruments of a universal character legislative acts of the Russian Federation in their systemic interpretation as well as acts of international organizations.

\section{Identification of problems and ways to solve them.}

The principles of legal regulation of relations in the field of aquaculture (fish farming), enshrined in the Law on Aquaculture.

The products of the fishing industry in Russia played a fairly important role in the country's economy. At the same time, until the 80 s of the last century, the extraction of fish and other water resources was carried out at the expense of fishing in the inland seas and the World Ocean. Fish farming was far from the first place in the supply of food raw materials, aquaculture developed poorly, its potential for providing high-quality fish products was not used.

In our opinion, this situation was caused by the lack of legislative regulation of artificial production of fish and water resources, the uncertainty of the legal regime of water bodies and fish-breeding infrastructure for the purposes of aquaculture, the ambiguity of the legal status of aquaculture objects, as well as the lack of clear regulation of administrative and contractual activities that formalize the relationship between the owners of land plots and water bodies and the economic entity.

To correct this situation, the Ministry of Agriculture of the Russian Federation approved the «Strategies for the Development of Aquaculture in the Russian Federation for the period up to 2020» (hereinafter referred to as the Development Strategy) on 10.09.2007 [4]. This document was of scientific and strategic importance, because through the development of the field of aquaculture, it determined not only the need to provide the country's population with a variety of affordable fish products, but also consolidated the goal of preserving biodiversity.

With the adoption of the Law on Aquaculture in the future, it became possible to implement the multifaceted national objectives of the Development Strategy:

1) providing the population with food of animal origin;

2) increased employment of the population, especially in rural areas and coastal areas;

3) reduction of import dependence in food supplies;

4) conservation of water bio-resources and biodiversity of aquatic animals and plants in their natural habitat.

The law on aquaculture enshrined the principles of legal regulation of relations in the field of aquaculture (fish farming), defined concepts, pointed out the features of the use of land and land for aquaculture purposes, defined the economic framework for the implementation of aquaculture, regulate the exercise of aquaculture, approved types of commercial aquaculture.

In importance, the Law on aquaculture contributes to the development of small and medium enterprises, creating conditions for attracting investment in aquaculture, is the basis for the development of intra-industry relations of science and aquaculture production, contributes to the expansion of related industries such as production of food, feed additives, aquaculture equipment and inventory. The Law on Aquaculture is aimed at improving the effectiveness of measures for the conservation and reproduction of aquatic bio-resources and their habitats. 
As Gabov A.V. rightly states, the Law on Aquaculture has a dual purpose: to provide the population with food and non-food fish products from aquaculture facilities and to preserve the stocks of aquatic bio-resources that will be replenished and restored through stocking (within the framework of pasture aquaculture and artificial reproduction of aquatic bio-resources). Gabov A.V. other authors of the scientific-practical review concludes: «the Value entered into force the Law on aquaculture cannot be overemphasized in the context of Russia's accession to the WTO, as in the new realities of the market development has intensified the support of domestic producers, and fisheries in that respect is no exception. Before its release, despite the abundance of legal acts, the regulation of commercial fish farming remained unsystematic and contradictory [5].»

The Law on Aquaculture is highly appreciated by both the scientific community and economic entities, which have tested in practice some of the provisions of the Law on Aquaculture. According to Timofeev L. A., Sorokina Yu. V., the implementation of the principles of legal regulation of relations in the field of aquaculture, proclaimed in the Law on Aquaculture, deserves positive assessments. The principles of legal regulation of relations in the field of aquaculture are reflected in a number of subsequent resolutions of the Government of the Russian Federation, which define the specifics of the implementation of fish farming [6].

According to the head of the Federal Agency for Fisheries Ilya Shestakov «Today, aquaculture is one of the most powerful drivers of the development of the fishing industry. Since the adoption of the relevant federal law, more than a 1.5 -fold increase in the volume of farmed fish has been achieved, and the production of salmon breeds has been doubled [7].»

After the introduction of the Law on Aquaculture, the Federal Agency for Fisheries provides the following statistics: at the end of 2016, the volume of production of commercial fish farming products in the Russian Federation amounted to 173.9 thousand tons, planting material-31.3 thousand tons. The volume of commercial aquaculture production in January-June 2017 exceeded 71 thousand tons, which is $12 \%$ more than in the same period last year. The fish-breeding stock in the Russian Federation amounted to 4491 fish-breeding plots with an area of about 544 thousand hectares. In use are 3151 fishbreeding plots with an area of 434 thousand hectares (more than $70 \%$ of the total number of plots). Of these, 1,876 fish-breeding plots, formed before the entry into force of the Law on Aquaculture, with an area of 354.2 thousand hectares, were re-registered without bidding. After the entry into force of the law, 2,615 fish-breeding plots with a total area of about 190 thousand hectares were formed [7].

Table 1. Dynamics of production of commercial aquaculture products on the example of the Southern Federal District and in the Russian Federation as a whole in 2014-2018 (thousand tons).

\begin{tabular}{|l|l|l|l|l|l|}
\hline $\begin{array}{l}\text { Federal District/subject of the Russian } \\
\text { Federation }\end{array}$ & 2014 & 2015 & 2016 & 2017 & 2018 \\
\hline Southern Federal District & 62.80 & 62.18 & 72.82 & 78.62 & 78.69 \\
\hline Rostov region & 21.82 & 21.24 & 23.41 & 26.99 & 28.45 \\
\hline Krasnodar Region & 19.77 & 19.65 & 21.99 & 22.89 & 22.52 \\
\hline Astrakhan region & 18.05 & 17.88 & 23.18 & 23.28 & 22.07 \\
\hline Republic of Crimea & 0.29 & 0.62 & 1.65 & 2.52 & 2.86 \\
\hline Volgograd region & 2.78 & 2.62 & 2.34 & 2.68 & 2.54 \\
\hline Republic of Adygea & 0.09 & 0.12 & 0.09 & 0.12 & 0.12 \\
\hline Sevastopol & 0.00 & 0.04 & 0.05 & 0.07 & 0.09 \\
\hline Republic of Kalmykia & 0.00 & 0.00 & 0.10 & 0.07 & 0.04 \\
\hline Total for Russia & 188.57 & 177.88 & 205.32 & 219.66 & 238.65 \\
\hline
\end{tabular}


In 2019, the volume of production of commercial fish products of aquaculture reached 248 thousand tons, which exceeds the indicators of 2018 by $20 \%$. According to the results of the first half of 2020, 169 thousand tons of aquaculture products were produced, which is $17 \%$ higher than in the first half of 2019. The amount of state support for the development of aquaculture amounted to almost 353 million rubles [7].

Aquaculture is defined in the Russian legislation as an activity related to the breeding and (or) maintenance, cultivation of aquaculture objects.

The Law on Aquaculture distinguishes between aquaculture (fish farming) related to agricultural production and aquaculture (fish farming), including acclimatization and artificial reproduction of aquatic biological resources related to the conservation of aquatic biological resources. The law emphasizes that commercial aquaculture (commercial fish farming) is a type of business activity related to agricultural production and is implemented in the form of: pasture, industrial, pond aquaculture.

Thus, aquaculture in the Russian Federation is an integral part of the agricultural and fisheries sector of the country's economy. In the fish-breeding technological process, all the basic principles, methods and techniques characteristic of breeding, reproduction and rearing of farm animals are used.

The Law on Aquaculture establishes five principles of legal regulation of legal relations in the field of aquaculture. These fundamental principles in the field of aquaculture are intended to become guidelines for further law-making, filling in gaps and eliminating conflicts of legal regulation in the field of fish farming.

The first principle indicates the purpose of aquaculture (fish farming) as an important component of human activity. Indeed, fish production has always been one of the main sources of food, provided jobs, and provided other economic benefits.

According to the FAO State of the World Fisheries and Aquaculture Report, about 179 million tons of fish were produced worldwide in 2018; total initial sales in monetary terms amounted to US \$ 401 billion; of which 82 million tons, estimated at US \$ 250 billion, were aquaculture products. Of this volume, 156 million tons, equivalent to $20.5 \mathrm{~kg}$ per capita per year, were used for human consumption. The remaining 22 million tons were intended for non-food use, primarily for the production of fish meal and fish oil. The aquaculture sector produced $46 \%$ of total production and $52 \%$ of fish for human consumption. China remained one of the largest fish producers, with $35 \%$ of the world's fish produced in 2018. For the rest of the regions, a significant share of production in 2018 was produced in Asia (34\%), followed by North and South America (14\%), Europe (10\%), Africa (7\%) and Oceania (1\%). In the last few decades, the total volume of fish production has increased significantly on all continents [8].

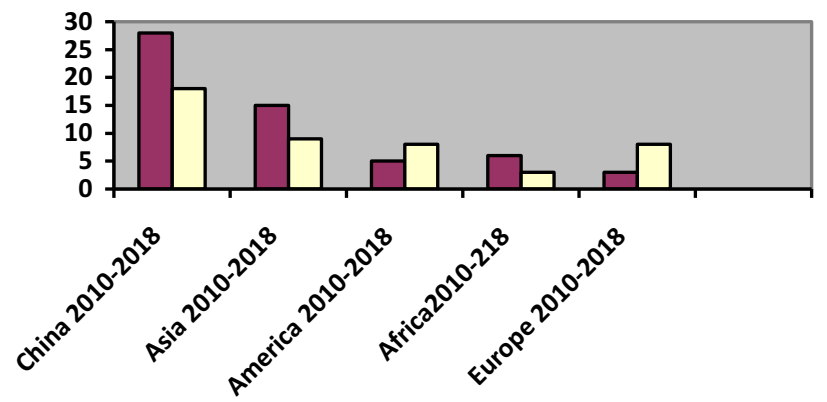

Fig.1.Share of regions in global aquaculture production (million Tons). 


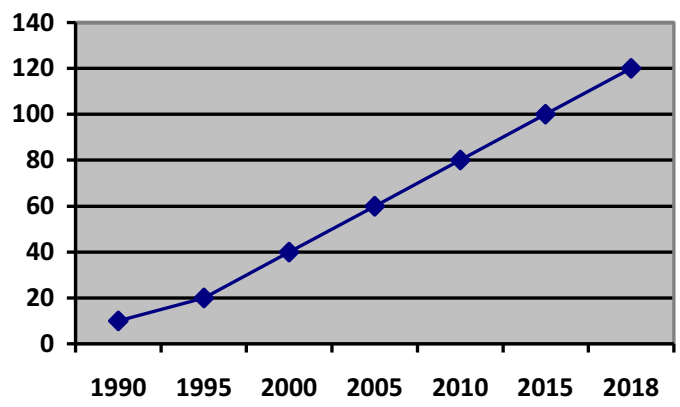

Fig.2. Global aquaculture production - aquatic animals and algae, 1990-2018 (million tons).

With the increase in the world's population, the deterioration of the ecological situation, uncontrolled fishing of water resources, and the growth of aquaculture products, it became obvious that living water resources are not infinite. In order to maintain economic wellbeing, it is necessary to establish effective management of fish farming activities.

The scientific world community came to the conclusion that due to the above factors, as well as as a result of illegal, unaccountable and unregulated fishing, the number of fish herds decreased, sometimes to critical values. The drastic destruction of fish species does not have the best effect on food security, hinders economic development, and reduces social well-being. The restoration of fish stocks, the preservation of those that have not been exterminated yet, requires not only political decisions and the improvement of legislation, but also the development of stable management. The development of aquaculture is a necessary measure to bridge the gap between the volume of production in fisheries and the increasing demand for agricultural products.

Articles 9.1 to 9.4 of the 1995 International Code of Conduct for Responsible Fisheries (hereinafter referred to as the Code) define responsible aquaculture [9]. The implementation of responsible aquaculture includes: monitoring in order to reduce at least the negative effects of aquaculture, proactive assessment of its impact on the ecosystem and the genetic diversity of its species, sustainable development of aquaculture, reflected in strategies and plans, prevention of harm to other economic activities of the local population.

Since the implementation of the Code of Conduct for Responsible Fisheries, there has been widespread recognition of the priority importance of the responsible use of fisheries and aquaculture resources. The Code has served as the basis for the development of international instruments, policies and programs that underpin efforts to manage resources responsibly at the global, regional and national levels.

The provisions of the Code are reflected in the national legislation of the participating countries, which makes it possible to discuss and regulate the problems of water depletion at the global level.

According to the second principle of legal regulation, the implementation of aquaculture (fish farming) is possible in ways that do not allow to damage to the environment and aquatic biological resources.

In the field of aquaculture, compliance with environmental safety is very important, since «Ensuring environmental safety is a set of environmental protection, engineering, technical and organizational measures aimed at preventing and reducing the negative impact on people's life and health, the natural environment, as well as their elimination» [10].

It is clear that fisheries management activities inevitably affect the size of target fish populations and may have an impact on other related or dependent species. The 
unsustainable use of fish resources reduces their ability to regenerate themselves, harms the health of ecosystems and impedes the conservation of biodiversity. Overfishing, environmental pollution, habitat destruction, and warming-related climate change, among other anthropogenic factors, can hinder food security and nutrition in the future, as well as reduce the viability of livelihoods in the long term.

For example, in January 2002, one of the most notorious crimes in Kamchatka in recent years was solved - the slaughter of salmon fry at the Ozerki fish hatchery. The crime was committed on February 6, 2001 at a salmon hatchery: unknown persons poisoned several million salmon fry with bleach, pouring it into a water intake well. The damage amounted to 12 billion rubles, and for the first time in domestic law enforcement practice, a criminal case was initiated under the article «Ecocide». There is no information about the imposition of punishment on the guilty, including information about the adoption of coercive measures to compensate for the damage caused in this case[11].

The issue of the impact of fish production and cultivation on the natural environment does not lose its relevance throughout the entire fisheries management activity. As a result of in-depth study of this problem, scientifically based approaches to management are being introduced. The concept of natural resource management is evolving and expanding by recognizing the need for biodiversity for sustainable production.

At the same time, it should be noted that the constant growth of fish production has a downside in the form of a threat to the water system. Possible consequences of fish farming in natural reservoirs in uncontrolled dynamically increasing volumes are algae pollution, an increase in the level of phosphorus and the number of bacteria, a decrease in the oxygen content, and so on. There is a constant need to adapt to changing environmental conditions and develop new standards for fish farming. The newly created standards of fish farming and aquaculture will help to prevent negative manifestations of aquaculture without compromising its productivity indicators.

We believe that this principle should be formulated in accordance with the international modern approach to ecology - a precautionary (or cautious) approach. The essence of this approach is to replace the response to the adverse consequences that have already occurred with their prevention, the use of proactive measures. However, in cases where there is a threat of serious or irreversible damage, the lack of full scientific certainty is not used as a reason to delay the adoption of cost-effective measures to prevent environmental degradation.

In accordance with article 6 of the Code, States, as well as sub-regional and regional fisheries management organizations, should widely practice a precautionary approach to the conservation, management and exploitation of living water resources in order to protect them and preserve the aquatic environment, taking into account the best available scientific data.

According to Bekyashev D. K., when making decisions on fisheries management, States are obliged to be guided by scientific data on the state of stocks of aquatic biological resources, and the absence of such data or the presence of unconfirmed data cannot serve as a basis or justification for not taking measures to conserve resources [12].

In addition, the principle under consideration should be supplemented by an indication of the inevitability of responsibility provided for by the current environmental legislation in relation to the field of aquaculture (fish farming). The right to a favorable ecological (environmental) environment is an inalienable right of everyone, and the interests of ensuring the safety of humanity include the interest of environmental safety, without which it is impossible to «sustainable development» of the entire human civilization [13].

Thus, it can be concluded that this principle is based on the provisions of Article 36 of the Constitution of the Russian Federation, which provides for the free use, possession and disposal of natural resources, if this does not cause damage to the environment. At the same 
time, it is obvious that the priority of environmental interests over economic ones is being fixed.

In accordance with the third principle, the legal regulation of public relations in the field of aquaculture is accompanied by the participation of citizens, public associations, associations of legal entities (associations and unions) in resolving issues related to aquaculture (fish farming), according to which these entities have the right to participate in the preparation of decisions, the implementation of which contributes to the development of aquaculture ( fish farming), and state authorities, local self-government bodies, subjects of economic and other activities are obliged to ensure the possibility of such participation in the manner and in the forms established by law. Direct use in practice of this principle is possible to solve such urgent problems in the field of aquaculture (fish farming), as the problems of the rights of ownership, use and disposal of water bodies in which the breeding and (or) maintenance, cultivation of aquaculture objects is carried out; legislative consolidation of the concepts of «watered quarry» and «pond», related to the regulation of pond aquaculture, as one of the varieties of commercial aquaculture.

Based on a comprehensive analysis of the Law on Aquaculture and other regulatory legal acts, it is necessary to specify the terminology in the legislation, specifying the terms: «watered quarry», «pond», «isolated pond» and others. The institution of separate water use for the implementation of aquaculture (fish farming) deserves more careful regulation. It seems reasonable to create more stringent prohibitions and restrictions for citizens only in relation to the rights to use the newly created ruslov ponds.

The above-mentioned principle should be applied in the daily activities of both public organizations and authorities at all levels. In order to implement this principle, economic entities and ordinary water and fish users, their public organizations at all levels (associations, associations, trade unions, etc.) should take control of the quality preparation of regulatory legal acts that will particularly affect practical fish farming activities. It is necessary to constantly monitor the public, as the most interested in the protection of the natural environment, for the implementation in practice of legislation on aquaculture (fish farming) by authorities at all levels.

In our opinion, this principle should be concretized either in the Law on Aquaculture or in subordinate legal acts. For example, it is necessary to clarify that the analyzed principle will allow: to receive from state authorities and local self-government bodies, their officials information about the protection of aquaculture facilities and the legal consequences of the activities of economic entities; to conduct a public environmental assessment of the consequences of negative implementation of aquaculture; to exercise public control over the protection of aquaculture facilities in the event of illegal implementation of aquaculture activities; to carry out, if necessary, measures for the protection and reproduction of aquaculture facilities; to promote the implementation of state programs in the field of aquaculture; to exercise other rights established by the legislation of the Russian Federation.

State authorities and local self-government bodies, when exercising their powers in the field of aquaculture (fish farming), should take into account the proposals and recommendations of citizens and public associations.

It is necessary to provide in the current legislation the procedure for interaction of state authorities and local self-government bodies with representatives of fishing organizations. World experience shows that in many states, the opinion of representative associations of fishermen is one of the key ones in the adoption of regulatory legal acts on fisheries issues [14].

The fourth principle of legal regulation of the field of aquaculture indicates the need to take measures to support the implementation and development of aquaculture (fish farming). 
For example, the State program «Development of the fisheries industry» approved by the resolution of the Government of the Russian Federation dated 15.04.2014 № 314[15], provided state support fish farms in the form of subsidies from the Federal budget to budgets of subjects of the Russian Federation for compensation of part of expenses for payment of percent on the loan agreements for the purchase of feed and fish stocking material for the development of commercial aquaculture; for the implementation of investment projects aimed at the development of commercial aquaculture; for the construction, reconstruction and (or) modernization of aquaculture infrastructure for the production of feed and fish stocking material for commercial aquaculture, processing facilities and storage of aquaculture products, as well as purchasing equipment, specialized vessels, vehicles and equipment for breeding, keeping and growing items; for the purchase of equipment for the breeding, maintenance and cultivation of sturgeon species, as well as for the construction, reconstruction and (or) modernization of fish-breeding infrastructure facilities for commercial sturgeon breeding.

State support for fish farms is also provided by the State Program approved by the Decree of the Government of the Russian Federation No. 717 of 14.07.2012 «On the State Program for the Development of Agriculture and Regulation of Markets for Agricultural Industry, Raw materials and Food» [16]. The state program provides for state support, including for the development of commercial aquaculture, which is a sub-branch of animal husbandry and related to agricultural production: for reimbursement of part of the cost of paying interest on loans received in Russian credit organizations and loans received in agricultural credit consumer cooperatives.

Since 2017, a new mechanism of state support for agriculture has been activated - a «single» subsidy that combines a number of areas of subsidies previously provided to regions to support agricultural producers, including grant support for small businesses. This state support is provided in accordance with the Rules for granting grants in the form of subsidies from the federal budget for the implementation of promising innovative projects in the agro-industrial complex under the sub-program «Technical and technological Modernization, innovative development» of the State Program.

The consolidation of the fifth principle of free and free access to information on the provision of fish farming areas for use is due to the fact that they are of interest to both private individuals and public authorities. Moreover, these interests are not always aimed at protecting water bodies and preserving their ecosystems. State authorities and local selfgovernment bodies systematically commit violations in the formation of land plots within the boundaries of which water bodies are located, providing such plots to individuals and legal entities. Due attention is also not paid to the observance of the interests of water users when conducting auctions for the conclusion of water use contracts. Water users and landowners are forced to become involved in legal disputes, which do not always end in their favor. The entrepreneurs themselves, who have received water objects for one reason or another, allow violation of the regime of use of reservoirs, being mistaken about the features of their legal regime.

Thus, the principle avoids corruption in the provision of, for example, land plots and water bodies for the implementation of aquaculture activities. It demonstrates the transparency and openness of the information needed in the field of aquaculture.

Information about the provision of fish-breeding areas for use should not be considered a commercial or official secret.

Further disclosure and clarification of the principle in the Law on Aquaculture partly helps to solve the problem of free access to information on the provision of fish farming areas for use.

Thus, fish-breeding areas are recognized as water bodies (parts of it), areas of the continental shelf and the exclusive economic zone of Russia used for fish farming. Their 
borders can be defined in accordance with the requirements of water legislation, legislation on the continental shelf and the exclusive economic zone. The relations that develop within the framework of the use of the continental shelf are very multifaceted; they fall into the field of regulatory influence of many branches, both international and domestic law [17]. A coastal State can always claim a shelf within 200 nautical miles of the coast. Under certain conditions, the shelf boundary extends no further than 350 miles [18].

For the organization of aquaculture (fisheries to aquaculture) is required to obtain a double permissions: decisions on allocation of water resources in use and permit their prey, as well as the conclusion of the contract of use fish plot [19]. In contrast to the industrial and coastal fisheries in the fisheries primary base is the decision of the administrative authority, and the terms of use fish footage complements. The existence of a contractualadministrative legal structure of the legal relationship allows this type of fishing to be attributed to mixed rights to natural resources.

For the purposes of aquaculture (fish farming), all types of water use provided for in Article 38 of the Water Code of the Russian Federation are allowed[20]. The specifics of water use for the purposes of aquaculture (fish farming) are established by the federal executive body authorized by the Government of the Russian Federation. By order of the Ministry of agriculture of Russia dated 06.04.2015 No. 129 «On approval of the characteristics of water use for the purposes of aquaculture (fish farming), peculiarities of the use of land for the purposes of aquaculture (fish farming) and the procedure for determining the characteristics of the creation and operation of buildings, structures, constructions for the purposes of aquaculture (fish farming)» characteristics of water use for the purposes of aquaculture (fish farming)[21].

27.12.2019 the Law on Aquaculture is supplemented by Article 5.1, according to which it is allowed to use agricultural land occupied by water bodies (flooded quarries and ponds, including ponds formed by water support structures on watercourses and used for the purpose of pond aquaculture) located within the boundaries of the land plot for the purpose of pond aquaculture. It is allowed to use the land plot for the implementation of activities provided for in the contract for the use of a fish-breeding plot that is in state or municipal ownership. The use of land or land plots that are in state or municipal ownership, without the provision of land plots and the establishment of an easement for the purposes of aquaculture (fish farming), is carried out in accordance with the land legislation[3].

According to part 1 of Article 39.6 of the Land Code of the Russian Federation, a lease agreement for a land plot that is in state or municipal ownership is concluded at an auction held in the form of an auction. A lease of land in state or municipal ownership is no bidding in the case of land to the person performing commodity aquaculture (fish farming commodity) under a contract of use fish plot of land in state or municipal ownership (hereinafter - terms of use fish section), for these purposes[22].

Comprehensive information about fish-breeding areas in accordance with the territorialadministrative division is freely available on the official website of the Federal Agency for Fisheries. Thus, an individual or legal entity can obtain information concerning the name of the fish-breeding site, its boundaries, area, type of use, the document-the basis for the formation of the boundaries of the site, as well as the terms of the auction [7].

The implementation of the principle of free and gratuitous access to information on the provision of fish-breeding areas for use is ensured by the need to comply with the industrywide principle of the right to a favorable environment. The content of the right to a favorable natural environment is very broad - it implies the right of citizens to participate in making environmentally important decisions, to access information on which state bodies base their decisions, as well as to information about negative changes in the environment, to the right to apply to the court for the restoration of violated rights and compensation for 
damage to life and health as a result of violation of the ecological balance from direct or indirect impact of economic decisions, etc [13].

We believe that the Law on Aquaculture must necessarily be supplemented with the principle on international cooperation in the field of aquaculture (fish farming). The Russian Federation carries out international cooperation in the field of environmental protection in accordance with the generally recognized principles and norms of international law and international treaties of the Russian Federation in the field of environmental protection. To some extent, about 60 international intergovernmental organizations are involved in international environmental cooperation at the global level, primarily: the International Maritime Organization (IMO), the Food and Agriculture Organization of the United Nations( FAO), the International Civil Aviation Organization( ICAO), the World Bank Group, the World Health Organization( WHO), the International Atomic Energy Agency (IAEA), the World Trade Organization (WTO), etc. The UN is trying to involve all international structures in a single process of international environmental cooperation.

The UN has approved a sustainable development plan for the period 2016-2030, which defines 17 Sustainable Development Goals (SDGs), accompanied by 169 targets. The environmental component of sustainable development is adequately reflected in this document and has become one of the most important priorities of the world community in the field of development for the next 15 years. The fisheries and aquaculture sector is actively involved in achieving SDG 14 «Conservation and sustainable use of the oceans, seas and marine resources for sustainable development». The FAO «Hand in Hand» initiative aims to establish contacts between donors and recipients of food system resources. Countries that are experiencing serious difficulties in terms of infrastructure, capacity and international support receive skills and technologies in a particular area, including in the field of aquaculture, as a result of working together with more successful countries. Russia should not be left out of this process, as it can gain invaluable experience in the field of aquaculture from countries such as China, the United States, and Norway, in turn, to help and share experiences with developing countries with low levels of aquaculture development. The level of development of aquaculture in Russia will be determined, among other things, by the use of international experience in the field of aquaculture.

Another necessary additional principle of legal regulation in the field of aquaculture (fishing), in our opinion, is expressed in the consolidation of the principle of a sciencebased policy for the implementation of aquaculture (fishing), the development of innovations in this area. The complexity of solving problems in the field of aquaculture (fish farming) related to food security, increased income from foreign trade and economic growth should be based on the doctrinal study of aquaculture, including taking into account of scientific, technical and economic achievements, forecasting, given the price of the product, income per capita, density and population growth. The state, in turn, should provide funding for scientific research, motivating the search for alternatives to declining catches with overexploitation of natural fish stocks.

Finally, among the principles of legal regulation of the sphere of aquaculture (fish farming), the principle of the inevitability of liability for violation of the legislation regulating relations in the field of aquaculture (fish farming) should find its place.

\section{Conclusion}

As shown by the study of sources regulating the field of aquaculture, aquaculture has existed for more than one millennium. This branch of agricultural production developed gradually by experience, taking into account traditions, mistakes made and through joint activities. Aquaculture has grown and integrated into the natural, social, economic and 
cultural environment. In the $70 \mathrm{~s}$, under the influence of technological progress in aquaculture, significant changes occurred. The sector is growing at an unprecedented rate and currently supplies more than half of the world's fish for human consumption. But its development also has adverse effects on the environment at the local, regional and global levels. In order to prevent the adverse consequences of the dynamic development of aquaculture, countries at the legislative level take measures for the legal, economically justified implementation of this type of activity.

In particular, in the Russian Federation, the Federal Law No. 148-FZ of 02.07.2013 «On Aquaculture (Fish Farming) and on Amendments to certain Legislative Acts of the Russian Federation» became a comprehensive legislative act regulating public relations in the field of aquaculture (fishing). According to this law, the legal regulation of relations in the field of aquaculture (fish farming) is carried out on five principles:

1) the importance of aquaculture (fish farming) as an important component of human activity;

2) the implementation of aquaculture (fish farming) in ways that do not allow damage to the environment and aquatic biological resources;

3) the participation of citizens, public associations, associations of legal entities (associations and unions) in solving issues related to aquaculture (fish farming), according to which these entities have the right to participate in the preparation of decisions, the implementation of which contributes to the development of aquaculture( fish farming), and state authorities, local self-government bodies, economic and other entities are obliged to ensure the possibility of such participation in the manner and in the forms established by law;

4) the adoption of measures of state support for the implementation and development of aquaculture (fish farming);

5) free and free access to information about the provision of fish-breeding areas for use.

The study of the list of principles of legal regulation of relations in the field of aquaculture (fish farming) showed that the Law on Aquaculture formulated the system of principles as closed. At the same time, some of the principles require additions.

In our view, the second principle should be brought into line with the International Code of Conduct for Responsible Fisheries of 1995, establishing a precautionary approach to the conservation, management and exploitation of living water resources in order to protect them and preserve the aquatic environment. The use of a precautionary approach will make it possible to take proactive measures to protect water resources.

The third principle should be specified either in the bylaws or in the legislation of the constituent entities of the Russian Federation. For these purposes, the Law on Aquaculture should explicitly indicate the need for the subjects of the Russian Federation to adopt an appropriate regulatory act that takes into account the specifics of the implementation of aquaculture (fish farming) in relation to the region.

In our opinion, the following principles are not unreasonably included in the principles of legal regulation of aquaculture activities by the legislator:

1) the international cooperation in the field of fish farming;

2) a science-based policy for the implementation of activities in the field of aquaculture( fisheries), the development of innovations;

3) the inevitability of liability for violation of the legislation regulating relations in the field of aquaculture (fish farming).

Thus, the Law on Aquaculture that we have studied needs further improvement, which will have a significant impact on the development of aquaculture activities.

\section{References}


1. L. Broslavsky, Laws and Realities of Russia, the United States and the European Union, 201 (2017)

2. A. Safonov, Moscow Economic Journal, 9, 519 (2019)

3. Federal Law No. 148-FZ of 02.07.2013 «On Aquaculture (Fish Farming) and on Amendments to Certain Legislative Acts of the Russian Federation»// ConsultantPlus

4. Federal Law No. 148-FZ of 02.07.2013 « On Aquaculture (Fish Farming) and on Amendments to Certain Legislative Acts of the Russian Federation»// ConsultantPlus

5. A. Gabov, Article-by-article scientific and practical commentary on the Federal Law "On Aquaculture (Fish Farming) and on Amendments to Certain Legislative Acts of the Russian Federation», 169, (2014)

6. L.Timofeev, Y. Sorokina, Bulletin of the Saratov State Law Academy, 4, 237-245 (2016)

7. Official website of the Federal Agency for Fisheries //http://fish.gov.ru/obagentstve/rukovoditel

8. Official website of the Food and Agriculture Organization of the United Nations (FAO)http://www.fao.org/home/ru/

9. International Code of Conduct for Responsible Fisheries, 1995 // http://www.fao.org/3/v9878e/v9878e00.htm

10. Y. Asaturov, O. Grechenkov, Collection of articles of the International Scientific and Practical Conference: in 2 parts, Environmental offenses in the field of the motor transport complex and measures to improve the effectiveness of legal regulation, 96-99 (2016)

11. O. Grechenkova, Eurasian Legal Journal, 9(100), 78-80 (2016)

12. D. Bekyashev, Monograph, 346 (2017)

13. O. Grechenkova, Journal of Advanced Research in Law and Economics, 3, 821-828 (2017)

14. O. Slepenkova, Commentary to Federal Law No. 166-FZ of December 20, 2004 «On Fisheries and Conservation of Aquatic Biological Resources» (article-by-article), 341 (2011)

15. State Program «Development of the Fisheries Complex», approved by the Decree of the Government of the Russian Federation of 15.04.2014 No. 314/ / ConsultantPlus

16. Resolution of the Government of the Russian Federation No. 717 of 14.07 .2012 «On the State Program for the Development of Agriculture and Regulation of Markets for Agricultural Industry, Raw Materials and Food»

17. S. Zyablitseva, O. Shakhverdieva, Eurasian Legal Journal, 1, 46-48 (2017)

18. S. Zjabliceva, J. Kuzmenko, Eurasian law journal, 1, 30-31 (2018)

19. D. Kozlov, Actual problems of Russian law, 1, 230-236 (2017)

20. Water code of the Russian Federation dated 03.06.2006 № 74-FZ// Consultant plus

21. Order of the Ministry of Agriculture of the Russian Federation No. 129 of 06.04.2015 « On Approval of the Features of Water Use for the purposes of Aquaculture (Fish Farming), the Features of Land Use for the purposes of Aquaculture (Fish Farming), as well as the procedure for determining the features of the creation and operation of buildings, Structures, structures for the purposes of aquaculture (fish farming)»//Consultant plus

22. Land Code of the Russian Federation No. 136-FZ of 25.10.2001// Consultant plus 